\title{
COMPREHENSIVE INVESTIGATION AND REMEDIATION OF CONCEALED KARST COLLAPSE COLUMNS IN RENLOU COAL MINE, CHINA
}

\section{Shuning Dong}

Xi'an Research Institute of China Coal Technology \& Engineering Group Corp., Xi'an, Shaanxi 710054, China, dongshuning@cctegxian.com

\section{Hao Wang}

Xi'an Research Institute of China Coal Technology \& Engineering Group Corp., Xi'an, Shaanxi 710054, China, wanghaoccteg@126.com

\section{Wanfang Zhou}

ERT, Inc., 12710 Buttonwood Lane, Knoxville, TN 37934, USA, zhou_wanfang@yahoo.com

\section{Abstract}

Coal mining in China has exposed numerous karst collapse columns of tens of meters in diameter and hundreds of meters in height. Hydraulically conductive collapses have functioned as groundwater pathways between the underground workings and the aquifers, resulting in water inrushes during coal mining. Over the last 40 years, water inrushes through these collapses have caused fatalities, economic losses, and degradation in the environment. Two such collapse features were unexpectedly encountered during operations in Renlou Coal Mine of China. The first encounter caused flooding of the entire mine. Although no serious damages occurred at the second encounter, because of timely and effective grouting measures, the production rate was reduced. Proactive detection of any concealed karst collapses and determination of their hydrogeological characteristics were essential components of a comprehensive investigation program in preventing water inrush incidents and ensuring normal coal production in the mine. The investigation program included surface and underground geophysical surveys with five geophysical techniques and directional drilling of three exploratory boreholes at completion depths ranging from 902 to $986 \mathrm{~m}$. A new collapse feature was identified through systematic analysis of the data collected in the investigation program. Although the bottom of the collapse feature has not been determined, its total height is more than $135 \mathrm{~m}$. The roof was at approximately $785 \mathrm{~m}$ depth, and there was an open void 1.5-2 m high at the top. Geotechnical properties, results from packer testing and tracer testing, monitoring of potentiometric pressures, and geochemical fingerprinting suggested that this collapse column was hydraulically conductive and still actively developing. Water in the confined thinbedded limestone and Ordovician limestone aquifer that either overlies or underlie coal seams could flow into the mining areas if this feature were not identified in advance but encountered during mining. A grouting program was designed and implemented to construct a water plug in the collapse that effectively cut off the hydraulic connections from the aquifers to underground workings. Successful construction of the water plug in the collapse was confirmed by water intake tests in the grouting holes, water flow measurements in the mining area, and groundwater level monitoring in the aquifer.

\section{Introduction}

Karst collapse columns are widely distributed in northern China. They have been found in over 50 coalfields and their total number exceeds 3,000 with an intensity of up to 70 collapses $/ \mathrm{km}^{2}$ (Zhou, 1997). In some mining panels, such collapse structures comprise $30 \%$ of the total mined areas. They are recognizable in plan view as patches of breccia with miscellaneous lithological composition, generally derived from overlying strata and completely enclosed in lower bedrock. Diameters range from tens to hundreds of meters with the largest measuring 1,050 $\mathrm{m}$ (Dong, 2016). In profile, they take the form of vertical cylinders several hundred meters deep. No bedding is apparent inside these structures and the different rocks are intermixed and poorly sorted. They generally contain higher proportions of displaced blocks and the adjoining strata are offset as a result of dissolution-collapse. Fragments tend to be sharply angular, typically rotated, show little sign of 
wear and appear to have dropped from their original stratigraphic position.

Usually the infill materials in the karst collapse structures are tabular 5-40 $\mathrm{cm}$ angular fragments, which display random orientation. Sides are subparallel, and contacts between host and fills are sharp and irregular. In most cases, the matrix consists of clastic sediments without cement or mineralization. These structures are generally perpendicular to the ground surface. However, they can become inclined as a result of tectonic movements but remain perpendicular to the surrounding strata. Voids may be present at the top of the structures and drill bits can drop noticeably during borehole drilling. Closed depressions sometimes form in the surficial sediments without any apparent fluctuation in water level or any construction works taking place.

The karst collapses found in northern China are of different hydrogeological types depending primarily upon the lithology of their internal rock blocks, extents of weathering and cementation, and the secondary structures associated with the collapses (Zhou and Beck, 2011). Based on the exposed karst collapses from drillings and excavations, the karst collapse columns can be permeable, impermeable and poorly permeable. In different karst collapses or different locations of the same collapse, the rock blocks may have different hydrogeological properties. The permeable collapses consist of weathered rock blocks but they are typically unconsolidated and not cemented. The impermeable collapses consist of weathered rock blocks that are cemented by weathered shale and mudstone. The poorly permeable collapses consist of partially cemented rock blocks with secondary fractures around the border of the collapses.

\section{Impacts of Karst Collapse Columns on Mining and the Environment}

The sudden inrush of karst water from the Ordovician limestone have been encountered in the mines of the Permo-Carboniferous coalfields of northern China. Karst collapse structures functioned as groundwater pathways for some of these events. Figure 1 shows three scenarios in which the pressurized karst water in the Ordovician limestone flows into the mining areas through karst collapse columns. The relative location of a mine to the active flow zone or karst conduits in karst aquifers determines the amount of water that can flow into the mine. In the presence of a large water-pressure difference, hydrofracturing will facilitate upward flow of the Ordovician karst water into mines. Apparently inactive karst collapse structures or those which have been cemented can be reactivated by activities such as mining, pumping water, dam construction, and landfill development. They may also be triggered by natural events such as neotectonic movements and earthquakes (Li and Zhou, 2015). Mining drifts do not have to intercept karst collapse structures directly to cause a geohazards but may instead intercept faults or fractures connected to them. However, once a water inrush occurs and significant water flows into the workings, the whole mine may become flooded. In cases where different aquifers, several hundred meters apart, become hydraulically connected, the impacts on safety, economy and the environment can be alarming.

Table 1 lists 14 water inrushes through karst collapse columns in coal mines, including the largest inrush in the world, which occurred in Fangezhuang Mine in 1984.
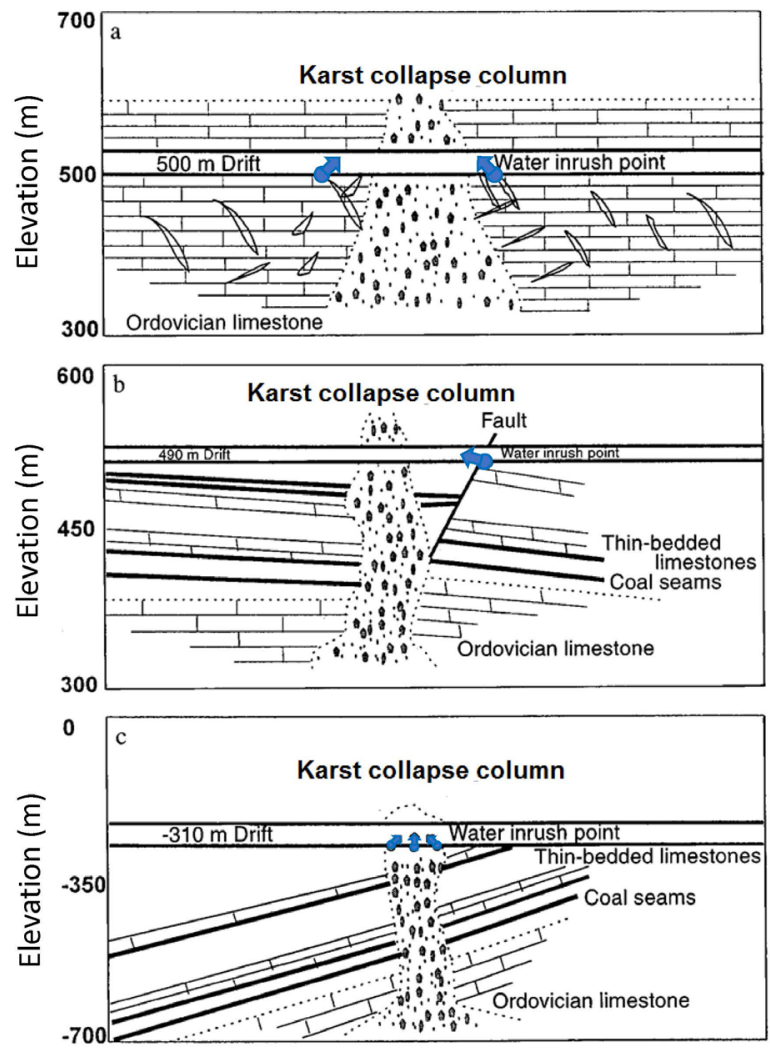

Figure la-c. Scenarios where karst water from Ordovician limestone flows into workings through karst collapse structures. (a) Through karst collapse-connected fissures; (b) through karst collapse-connected faults; (c) through karst collapse columns (modified from Zhou, 1997). 


\begin{tabular}{|c|c|c|c|c|}
\hline Mine & Date & $\begin{array}{l}\text { Flow } \\
\text { rate } \\
\left(\mathrm{m}^{3} / \mathrm{s}\right)\end{array}$ & Description & Damage \\
\hline $\begin{array}{l}\text { Taoyuan Coal } \\
\text { Mine }\end{array}$ & 2013 & 2.8 & $\begin{array}{l}\text { Karst water from the Ordovician limestone flowed into the cut-hole of } \\
1035 \text { working panel through a concealed karst collapse. }\end{array}$ & $\begin{array}{l}\text { Mine was flood with } 1 \\
\text { person missing. }\end{array}$ \\
\hline $\begin{array}{l}\text { Shenjia-zhuang } \\
\text { Coal Mine }\end{array}$ & 2012 & 0.36 & $\begin{array}{l}\text { Karst water from the Ordovician limestone flowed into mine through } \\
\text { a concealed karst collapse that has developed to } 50 \mathrm{~m} \text { below the coal } \\
\text { seam. }\end{array}$ & Mine was flooded. \\
\hline $\begin{array}{l}\text { Huangsha Coal } \\
\text { Mine }\end{array}$ & 2011 & 3 & $\begin{array}{l}\text { Karst water from the Ordovician limestone flowed into working panel } \\
112106 \text { at depth of } 800 \mathrm{~m} \text { through a compound structure consisting of } \\
\text { karst collapse column and a fracture. }\end{array}$ & Mine was flooded. \\
\hline $\begin{array}{l}\text { Luotuoshan Coal } \\
\text { Mine }\end{array}$ & 2010 & 2 & $\begin{array}{l}\text { Karst water from the Ordovician limestone flowed into mine via } 870 \mathrm{~m} \\
\text { return airway of \#16 coal seam. }\end{array}$ & $\begin{array}{l}\text { Mine was flooded with } \\
32 \text { fatalities. }\end{array}$ \\
\hline $\begin{array}{l}\text { Dongpang Coal } \\
\text { Mine }\end{array}$ & 2003 & 19.5 & Karst water from a karst collapse structure flowed into the mining area. & Mine was flooded. \\
\hline $\begin{array}{l}\text { Wucun Coal } \\
\text { Mine }\end{array}$ & 1999 & 0.67 & Karst water from a karst collapse structure flowed into the mining area. & Panel was flooded. \\
\hline $\begin{array}{l}\text { Renlou Coal } \\
\text { Mine }\end{array}$ & 1996 & 19 & $\begin{array}{l}\text { Karst water flowed into } 7222 \text { working face at depth of } \sim 380 \mathrm{~m} \text { through } \\
\text { a karst collapse column. The collapse connected thin-bedded limestone } \\
\text { and Ordovician limestone with the mining area. }\end{array}$ & $\begin{array}{l}\text { Mine was flooded, shut } \\
\text { down about } 6 \text { months. }\end{array}$ \\
\hline $\begin{array}{l}\text { Huaxian Coal } \\
\text { Mine }\end{array}$ & 1984 & 0.06 & $\begin{array}{l}\text { Karst water from a karst collapse structure flowed into surrounding } \\
\text { fractures and then into the horizontal drift in the Ordovician limestone. }\end{array}$ & Drift was abandoned. \\
\hline $\begin{array}{l}\text { Fagezhuang Coal } \\
\text { Mine, Kailuan }\end{array}$ & 1984 & 34 & $\begin{array}{l}\text { This is the biggest water inflow incident in the world. The mining coal } \\
\text { seam was } 180 \mathrm{~m} \text { above the Ordovician limestone but they are connected } \\
\text { by a karst collapse structure. The reactivation of the collapse may be } \\
\text { associated with a recent earthquake in this area. Grouting boreholes } \\
\text { revealed that the top of the sinkhole was unfilled with sediments. }\end{array}$ & $\begin{array}{l}\text { Mine was flooded, } \\
\text { resulted in } 9 \text { fatalities, } \\
17 \text { cover sinkholes, } \\
\text { and the adjacent three } \\
\text { mines were threatened. }\end{array}$ \\
\hline $\begin{array}{l}\text { Fagezhuang Coal } \\
\text { Mine, Kailuan }\end{array}$ & 1983 & 0.23 & $\begin{array}{l}\text { A small fault with displacement of } 0.2-0.5 \mathrm{~m} \text { was intercepted by a } \\
\text { working stope. Karst water flowed through a karst collapse structure } \\
\text { into the fault and then to the working stope. }\end{array}$ & $\begin{array}{l}\text { Working stope was } \\
\text { flooded. }\end{array}$ \\
\hline $\begin{array}{l}\text { Fagezhuang Coal } \\
\text { Mine, Kailuan }\end{array}$ & 1978 & 1 & $\begin{array}{l}\text { Water flowed into the mine from the sandstone, which is } 160 \mathrm{~m} \text { above } \\
\text { the underlying Ordovician limestone. A sluice gate was constructed } \\
\text { to isolate the water inflow area and a } 0.2-\mathrm{m} \text { fracture was revealed, } \\
\text { connected with a karst collapse structure. }\end{array}$ & $\begin{array}{l}\text { Part of a drift and a } \\
\text { working stope }(70,188 \\
\text { m3) was flooded }\end{array}$ \\
\hline $\begin{array}{l}\text { Lifeng Coal } \\
\text { Mine, Jiaozuo }\end{array}$ & 1967 & 2 & $\begin{array}{l}\text { Karst developed very well in the area. Intensive mine water drainage } \\
\text { reactivated the karst collapse structure. }\end{array}$ & $\begin{array}{l}\text { A working stope was } \\
\text { flooded and } 1 \text { fatality } \\
\text { occurred. }\end{array}$ \\
\hline $\begin{array}{l}\text { Huoxian Coal } \\
\text { Mine }\end{array}$ & 1967 & 0.13 & $\begin{array}{l}\text { Karst water flowed into an excavating drift through a karst collapse } \\
\text { structure and a connecting fault. }\end{array}$ & Drift was abandoned. \\
\hline $\begin{array}{l}\text { Tongyie Coal } \\
\text { Mine, Anyuang }\end{array}$ & 1965 & 0.39 & $\begin{array}{l}\text { A water inspection borehole drilled into a karst collapse structure from } \\
\text { a drift. The initial water flow rate was } 0.5 \mathrm{~m}^{3} \mathrm{~min}^{-1} \text { and water flow rate } \\
\text { increased to } 23.3 \mathrm{~m}^{3} \mathrm{~min}^{-1} \text {. An exploration borehole revealed } 17 \text { cavities } \\
\text { within } 50 \mathrm{~m} \text { of the collapse with the maximum bit-drop of } 2.59 \mathrm{~m} \text {. }\end{array}$ & Mine was flooded. \\
\hline
\end{tabular}

Table 1. Case histories of water inrushes through karst collapse columns in northern China.

Karst water gushed into the mine at a flow rate of $34 \mathrm{~m}^{3} / \mathrm{s}$ at a depth of $313 \mathrm{~m}$ below sea level (bsl). The surface level is $27 \mathrm{~m}$ above sea level (asl). The whole mine was flooded within $21 \mathrm{~h}$ and as a result, the regional water table in the Ordovician limestone dropped from $5.94 \mathrm{~m}$ asl to $111.09 \mathrm{~m}$ bsl. The cone of water depression covered $84 \mathrm{~km}^{2}$ with a north-south axis of $25 \mathrm{~km}$. The fall in the level of the water table in the Ordovician limestone caused serious problems for local residents. These included the drying up of their water supply wells, contamination of the groundwater, and the formation of new sinkholes. The water inrush led to the development of 17 cover collapses, with resulting sinkholes ranging in diameter from 2.5 to $3 \mathrm{~m}$ and with depths of 3 to $12 \mathrm{~m}$.
Table 1 also includes a water inrush that occurred at the study mine, Renlou Coal Mine, Anhui province in 1996. The water inrush occurred in working panel 7222 at $380 \mathrm{~m}$ deep. Figure 2 shows the lithology in the mine and the water-inrush point. The panel was flooded within $10 \mathrm{~h}$. The final water level was stabilized at $15.59 \mathrm{~m}$ asl, which is approximately the same elevation of the water level in the Ordovician limestone. The maximum water inflow was $19 \mathrm{~m}^{3} / \mathrm{s}$. The water inrush resulted in a water level drop of $7.04 \mathrm{~m}$ in an Ordovician limestone monitoring well $16.2 \mathrm{~km}$ away. Investigations in response to the water inrush and subsequent grouting confirmed that the water pathway was a karst collapse column. The column was nearly vertical and oval-shaped with long 
axis of $30 \mathrm{~m}$ and short axis of $25 \mathrm{~m}$. Although none of the boreholes reached the bottom of the collapse column, the collapse column was at least $300 \mathrm{~m}$ high, having its root in the Ordovician limestone and roof in the Quaternary and Tertiary formations. The top section of the karst collapse column consisted of an open void, which suggests that the sinkhole was still actively developing upward. The mine was restored six months later after a successful grouting program.

A second smaller water inrush occurred at working panel $7_{2} 18$ in the same coal mine in 1999 . Timely recognition of water inrush indicators including pressure increase in front of the tunnel, deformation of tunnel support structures, water flow increasing from 5 to $9 \mathrm{~m}^{3} / \mathrm{h}$ allowed

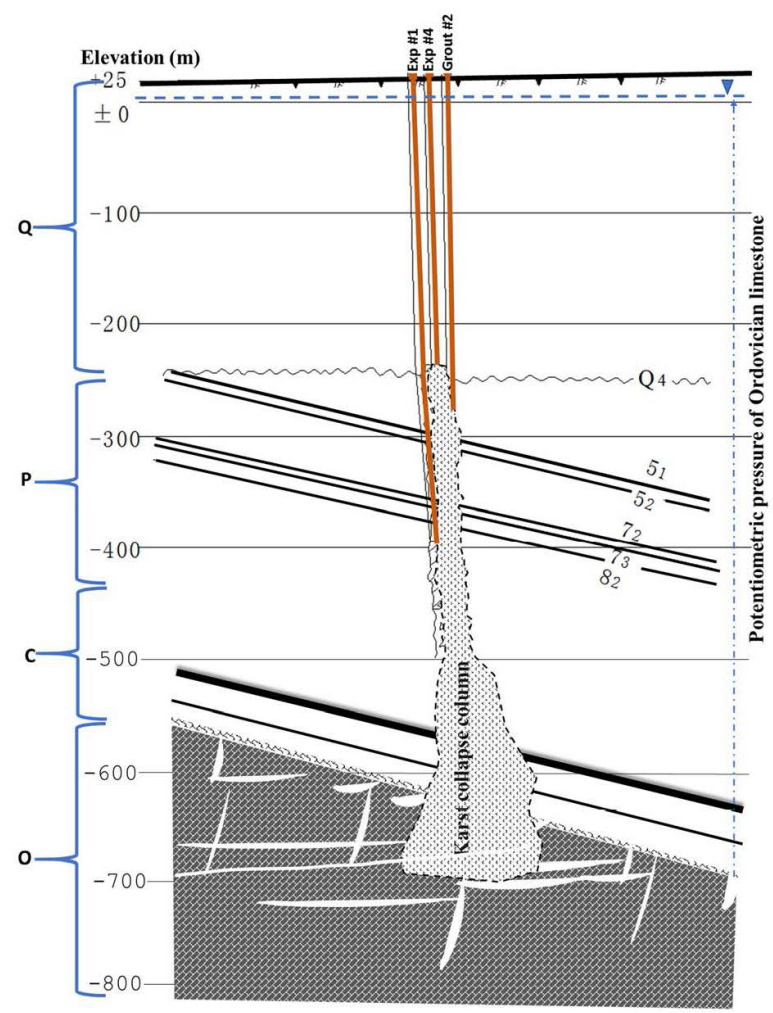

Q- Quaternary and Tertiary formations consisting of 4 aquifers and 3 aquicludes. They unconformably overly Permian coal measures.

P - Permian coal measures consisting of 10 coal seams labeled \#1 through 11 from top down. Coal seams are often overlain and/or underlain by thin-bedded limestones. Overall, they are not strong aquifers.

C-Carboniferous formations consisting of 7 coal seam from \#12 through 18 Majority is of no commercial value. They are typically overlain by thin-bedded limestones. Specific capacity at boreholes ranges from 0.1243 to $0.1558 \mathrm{~L} / \mathrm{s} . \mathrm{m}$. Bauxite is at bottom of this formation.

O-Ordovician limestone with extensive karst development in top $100 \mathrm{~m}$. Largest cavity encountered in boreholes is $7.6 \mathrm{~m}$ high. Specific capacity at boreholes is $2.712 \mathrm{~L} / \mathrm{s} . \mathrm{m}$. Elevation of potentiometric pressure is $\sim 6.45 \mathrm{~m}$.

Figure 2. Schematic depicting lithology and 1996 water Inrush at Renlou Coal Mine, China. quick responses so that the risk for a catastrophic water inrush was mitigated by systematic investigation and grouting. No serious damages occurred at the second encounter with production rate slightly affected. The investigation confirmed that this water inrush was also through a karst collapse column that was oval-shaped with its long axis of $40 \mathrm{~m}$ and short axis of $30 \mathrm{~m}$. It has developed to a position approximately $20 \mathrm{~m}$ below \#8 coal seam. This collapse was also actively developing upward.

These water inrush incidents suggest that the hydrogeological conditions in Renlou Coal Mine meet the three basic requirements for a water inrush through karst collapse columns:

1. Presence of a karst aquifer that can supply a sustainable or high volume of water;

2. Active karst collapse columns that are permeable to water; and,

3. Significantly higher water pressure in the karst aquifer than the elevation of the underground working area, providing the necessary force for water flow.

Therefore, proactive detection of any concealed karst collapses and determination of their hydrogeological characteristics have become essential components of a comprehensive investigation program in preventing water inrush incidents and ensuring normal coal production in the mine.

\section{Detection and Remediation of a Concealed Karst Collapse Column}

In June 2010, an anchor hole advanced in II $5_{1}$ Tunnel encountered groundwater. The tunnel was at elevations from -718.6 to $-720.1 \mathrm{~m}$ bsl and was excavated for mining $\# 5$, coal seam. The tunnel was $440 \mathrm{~m}$ below the Quaternary and Tertiary formations and at least $300 \mathrm{~m}$ above the Ordovician limestone. The stratigraphy encountered by the tunnel consisted of fine sandstone and mudstone with petrified plant parts. Under normal conditions, water in these formations was limited and did not pose a safety threat to underground workings. The tunnel also intercepted a normal fault, $\mathrm{DF}_{8}$, with $5 \mathrm{~m}$ displacement. No water seepage was observed through the fault. 


\section{Water Source Discrimination by Temperature and Hardness Measurements}

As shown in Figure 3, two exploration boreholes, 4-3 and 4-3', were advanced at different angles to investigate the source and pathway of the groundwater encountered at the anchor hole. At an angle of $47^{\circ}$, borehole 4-3 intercepted fault $\mathrm{DF}_{8}$, whereas at an angle of $40^{\circ}$, borehole $4-3^{\prime}$ intercepted a high-angled $\left(75^{\circ}\right)$ fracture. The maximum groundwater flow rate at borehole 4-3 was $2 \mathrm{~m}^{3} / \mathrm{h}$, and the maximum flow rate at borehole 4-3' was $16 \mathrm{~m}^{3} / \mathrm{h}$.

Figure 4 shows changes of water temperature and hardness at borehole 4-3 from June 2010 to November 2011. Data at borehole 4-3' had similar trends. Over a period of 17 months, the water temperature gradually increased from 33 to $41^{\circ} \mathrm{C}$. The normal earth temperature at this elevation in the mine is approximately $35^{\circ} \mathrm{C}$. The higher than normal temperature in the inflow water indicated that the water source was from deeper formations.

Two types of hardness are presented in Figure 4, the total hardness was measured prior to boiling and permanent hardness was measured after boiling. Their unit is degree of General Hardness or German degree (dGH). Both types of hardness show a general trend of increase. The total hardness increased from 8.34 to $60.58 \mathrm{dGH}$, whereas the permanent hardness increased from 0 to $48.81 \mathrm{dGH}$. The persistent increases in the hardness also suggest that the water sources were from the deeper formations. The measured temperature and hardness at end of the monitoring period were similar to those measured in the Ordovician limestone in the mine.

\section{Geophysical Investigations}

Geophysical surveys were conducted to investigate any geologically and hydrogeologically anomalous areas. Time domain electromagnetic methods (TDEM) and 3D seismic were used on the ground surface, while TDEM, 3D seismic, earth resistivity imaging, and ground penetrating radar were used underground in II 5, Tunnel. Areas identified and verified from multiple geophysical techniques were considered the targets for further investigations. Figure 5 shows an example of 3D seismic interpretation of the $\# 5$, coal seam elevation. The rectangular is a geophysical anomaly in which the coal seam elevations were disconnected. A vertical profile
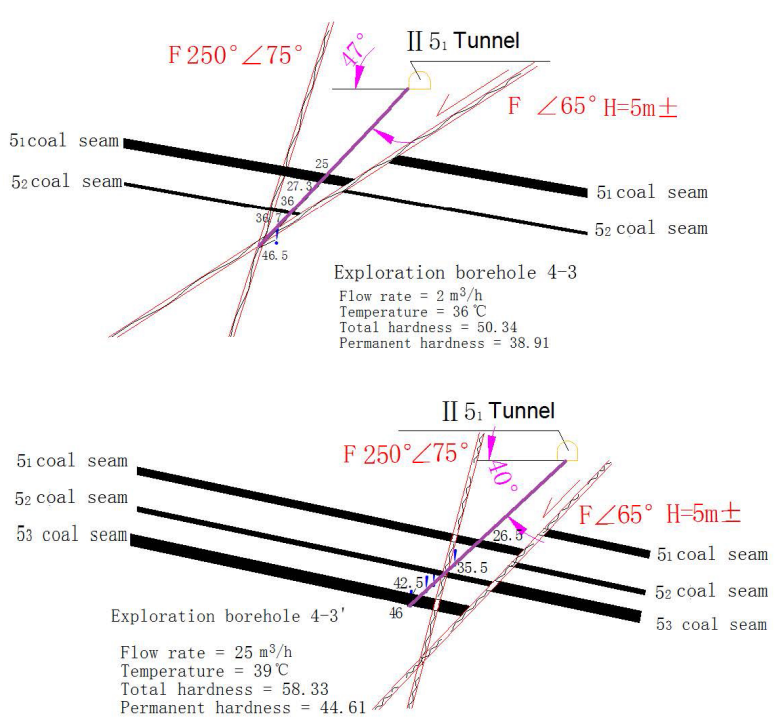

Figure 3. Layout of boreholes 4-3 and 4-3' for exploration of water sources.

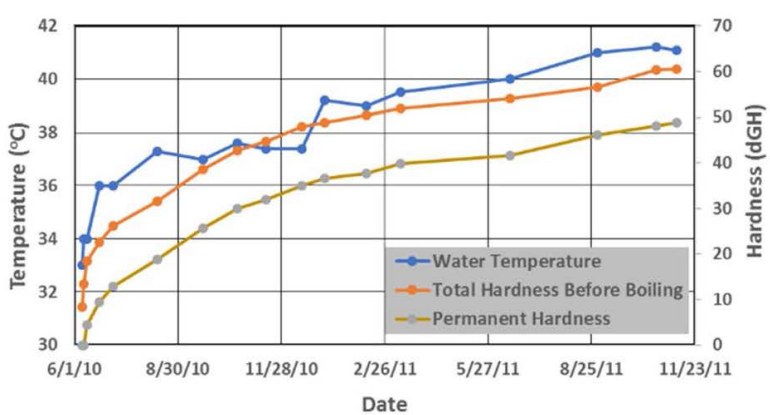

Figure 4. Water temperature and hardness measurements at borehole 4-3.

of the 3D seismic is shown in Figure 6. The location of the cross-section is shown in Figure 5. The geophysical anomaly was interpreted to be associated with a karst collapse column.

\section{Borehole Exploration}

Figure 5 shows the locations of three exploratory and grouting boreholes $\# 1, \# 2$, and $\# 3$, and two monitoring wells $\# 23$ and \#24. The monitoring wells were installed to monitor potentiometric pressures of the Ordovician limestone. The exploratory boreholes were drilled in the order of $\# 1, \# 2$, and $\# 3$. They were drilled in the geophysically interpreted anomaly to investigate the subsurface conditions, in particular, to determine presence of a karst collapse column. If the karst collapse column was confirmed, these boreholes were then used as grouting holes to construct a water plug within the collapse feature. Borehole \#1 was vertical, while directional drilling was used in boreholes $\# 2$ and $\# 3$ to intercept the collapse feature encountered in 


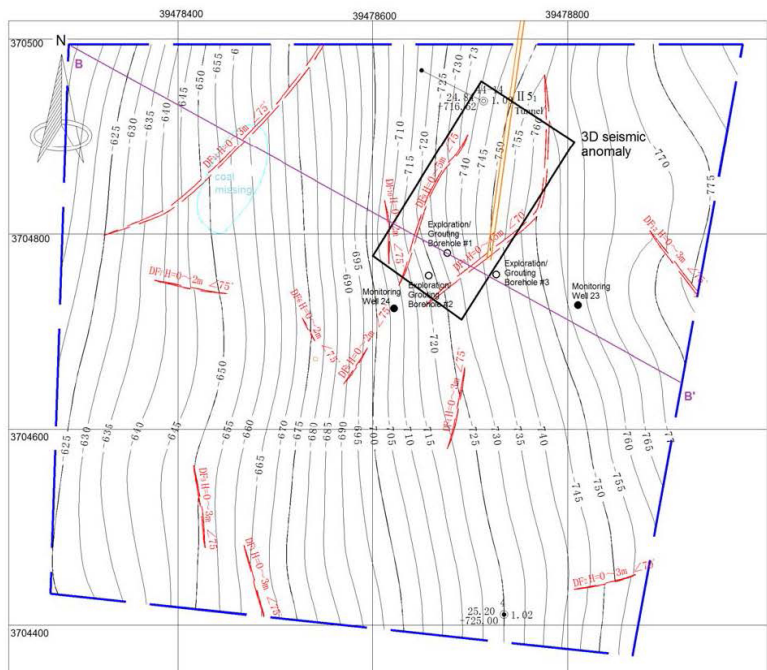

Figure 5. Contours of 5, coal seam elevation as interpreted from 3D seismic survey.

borehole \#1. Figures 7 and 8 shows the profiles across from borehole \#1 through borehole \#2 to monitoring well 24 and from borehole \#1 through borehole \#3 to monitoring well 23 , respectively. Table 2 summarizes the pertinent parameters for these three boreholes.

Both boreholes \#1 and \#2 encountered drill bit drops and total loss of circulation. The bit drops at boreholes \#1 and $\# 2$ were $1.5 \mathrm{~m}$ and $2 \mathrm{~m}$, respectively. The loss of circulation was greater than $72 \mathrm{~m}^{3} / \mathrm{h}$ where the drill bit drops occurred. The drops occurred at depths between 773 and $787 \mathrm{~m}$. Such characteristics were atypical of the formations at these intervals unless a karst collapse

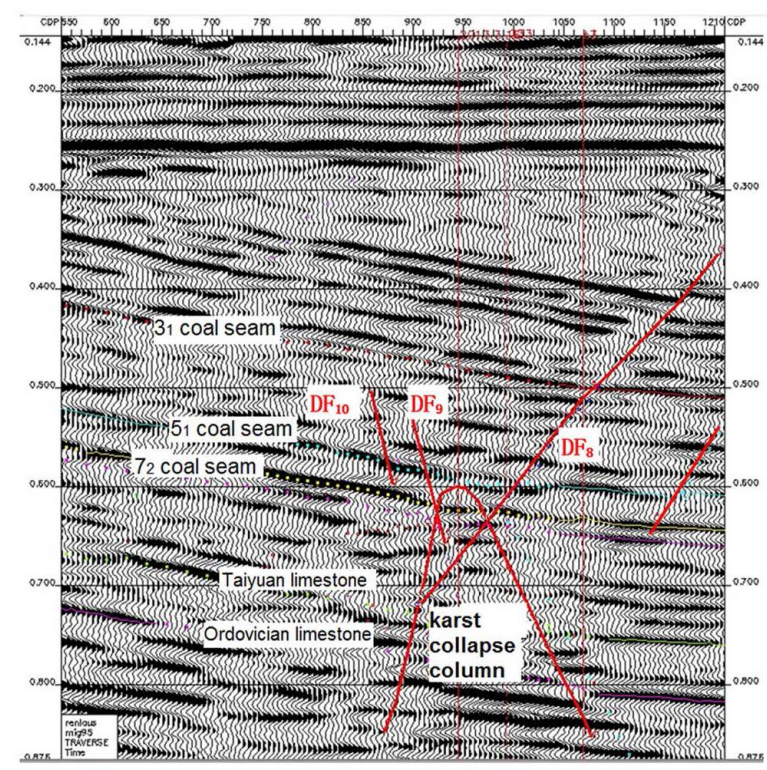

Figure 6. A cross-section of 3D seismic survey (location of the cross-section is shown in Figure 5).

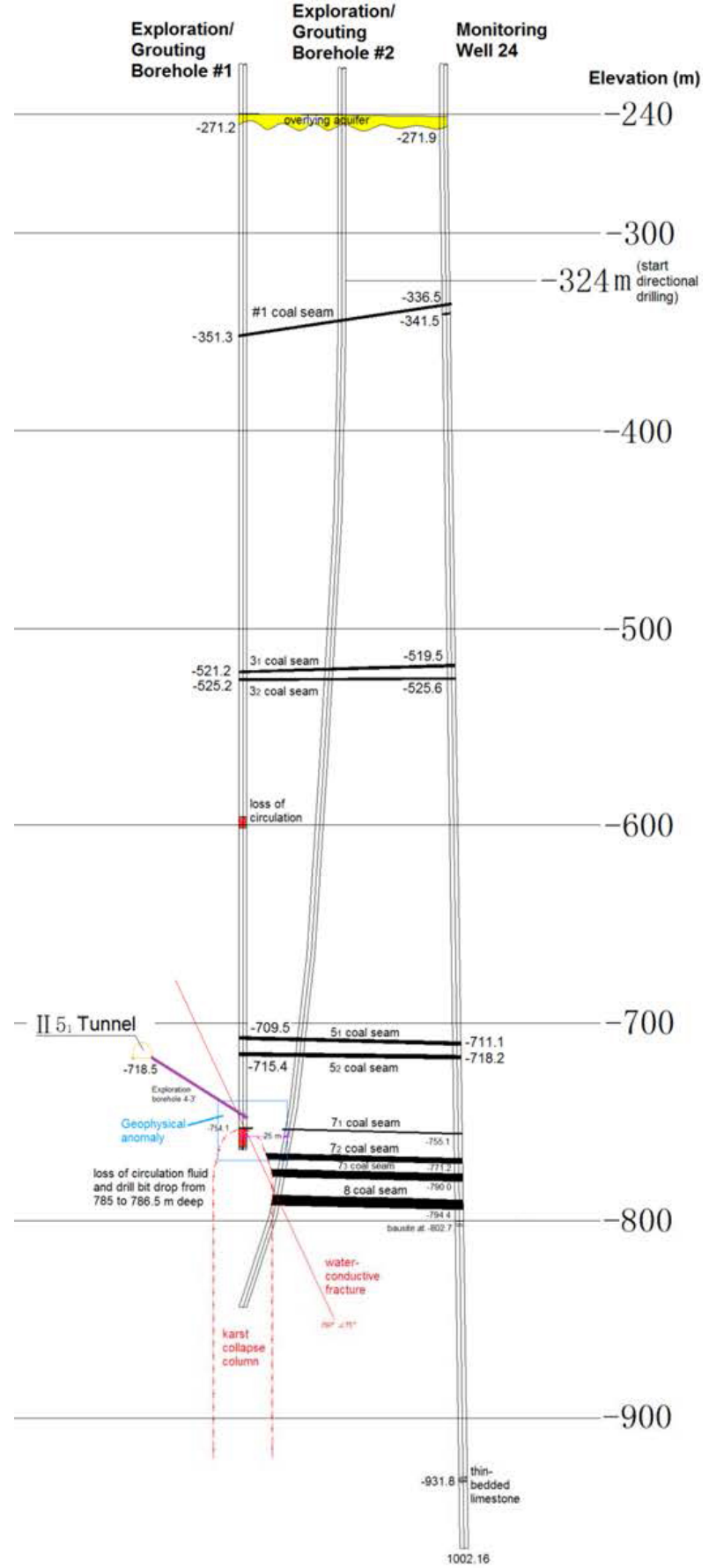

Figure 7. Profile of exploration/grouting boreholes \#1 and \#2.

column or large fracture was present. The exploratory and geophysical results suggested that this feature was likely a karst collapse column. The column had an oval shape, and its dimensions were estimated to be $55 \mathrm{~m}$ in the long axis and $40 \mathrm{~m}$ in the short axis. The bottom of the karst collapse column was unknown and its roof was approximately $20 \mathrm{~m}$ below \#5 coal seam. 


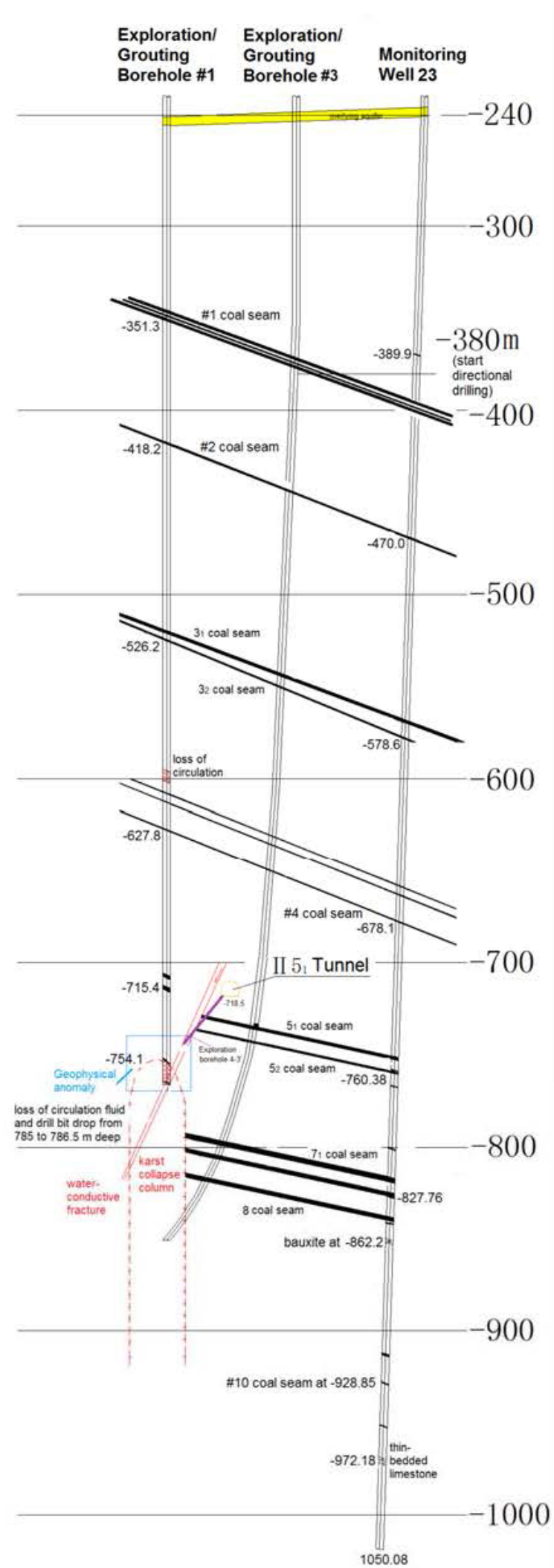

Figure 8. Profile of exploration/grouting boreholes \# 1 and \#3.

\begin{tabular}{|c|c|c|c|}
\hline \multirow{2}{*}{ Parameters } & \multicolumn{3}{|c|}{ Exploration/Grouting Boreholes } \\
\hline & $\# 1$ & $\# 2$ & $\# 3$ \\
\hline Total depth (m) & 920.48 & 920.57 & 986 \\
\hline $\begin{array}{l}\text { Directional } \\
\text { drilling }\end{array}$ & & $\begin{array}{c}\text { At } 350 \mathrm{~m} \\
\text { toward borehole } \\
\# 1\end{array}$ & $\begin{array}{c}\text { At } 380 \mathrm{~m} \\
\text { toward } \\
\text { borehole \#1 }\end{array}$ \\
\hline $\begin{array}{l}\text { Depth to } \\
\text { bedrock (m) }\end{array}$ & 271.2 & 273.7 & 273.1 \\
\hline $\begin{array}{l}\text { Depth to \#1 coal } \\
\text { seam }(\mathrm{m})\end{array}$ & 376.8 & $360.0-369.6$ & 395.05 \\
\hline $\begin{array}{l}\text { Depth to } \# 5 \text { coal } \\
\text { seam }(m)\end{array}$ & 740.8 & 764.9 & 758.7 \\
\hline $\begin{array}{l}\text { Loss of } \\
\text { circulation } \\
\text { intervals }(\mathrm{m})\end{array}$ & $\begin{array}{l}627-694 \\
785-787\end{array}$ & $\begin{array}{c}609-619 \\
773-775 \\
863-865 \\
885\end{array}$ & $\begin{array}{l}739 \\
983\end{array}$ \\
\hline $\begin{array}{l}\text { Drilling bit drop } \\
\text { (m) }\end{array}$ & $\begin{array}{c}1.5 \mathrm{~m} \\
\text { from } 785 \\
\text { to } 786.5 ; \\
\text { likely } \\
\text { entering } \\
\text { collapse } \\
\text { body }\end{array}$ & $\begin{array}{l}2 \mathrm{~m} \text { from } \\
773 \text { to } 775 \\
\text { likely entering } \\
\text { collapse body }\end{array}$ & \\
\hline Grouting (t) & $\begin{array}{l}1,366 \mathrm{t} \\
(935 \mathrm{tons} \\
\text { at } 791 \mathrm{~m} ; \\
81 \mathrm{t} \text { at } \\
820 \mathrm{~m} ; \\
159 \mathrm{t} \text { at } \\
842 \mathrm{~m} ; \\
191 \mathrm{t} \text { at } \\
900 \mathrm{~m})\end{array}$ & $\begin{array}{c}1,920 \mathrm{t}(445 \mathrm{t} \text { at } \\
803 \mathrm{~m} ; 245 \mathrm{t} \text { at } \\
835 \mathrm{~m} ; 180 \mathrm{t} \text { at } \\
855 \mathrm{~m} ; 110 \mathrm{t} \text { at } \\
865 \mathrm{~m} ; 270 \mathrm{t} \text { at } \\
865.5 \mathrm{~m} ; 140 \mathrm{t} \\
\text { at } 885 \mathrm{~m} ; 70 \mathrm{t} \text { at } \\
905 \mathrm{~m} ; 420 \mathrm{t} \text { at } \\
920.57)\end{array}$ & $\begin{array}{l}295 \mathrm{t} \text { at } \\
911 \mathrm{~m}\end{array}$ \\
\hline $\begin{array}{l}\text { Post-grouting } \\
\text { water intake } \\
\text { capacity (L/ } \\
\text { min.m.m) }\end{array}$ & 0.00099 & 0.00091 & 0.00214 \\
\hline
\end{tabular}

Table 2. Summary of drilling parameters at three exploration/grouting boreholes.

Grouting at boreholes \#1 and \#2 further confirmed that both boreholes intercepted the top of a collapse column. Grouting materials injected at borehole \#1 were observed at borehole \#2 as well as in II 5. Tunnel. Since borehole \#3 was advanced after grouting at boreholes \#1 and \#2 was completed, it encountered cement-filled void and the amount of grout was significantly reduced in borehole \#3. Water injection tests were conducted at all three boreholes before completing the grouting. The results (Table 2) demonstrated that the water intake capacity was less than the designed value of $0.01 \mathrm{~L} / \mathrm{min} . \mathrm{m} . \mathrm{m}$. The water intake capacity was calculated by water injection rate $(\mathrm{L} / \mathrm{min}$ ) divided by applied pressure ( $\mathrm{m}$ of water) and test interval $(\mathrm{m})$. Another indicator of the grouting success was that the post-grouting groundwater flow into II 5 , Tunnel was minimal and the remaining water seeped from the overlying formations with their typical 
water quality parameters. The water levels in monitoring wells 23 and 24 have been measured to ensure the longterm success of the investigation and remediation effort.

\section{Conclusions}

Karst collapse structures are karst features that were often encountered in mines of northern China. Because these karst features could be several hundred meters high, they can connect multiple aquifers and lead water to underground working under the following conditions:

1. The karst collapse column is active and permeable to water.

2. The karst collapse column is connected to an aquifer or a water body that can supply a sustainable water source.

3. The water pressure in the aquifer or water body is higher than the elevation of the underground working area.

Because of potential damages that can be caused by these structures in mines, proactive detection of any concealed karst collapses and determination of their hydrogeological characteristics are essential components of mine water control and prevention programs in China. Multiple techniques including geochemistry, geophysics, directional drilling, grouting, and water injection testing were used in this case study. The risks posed by a karst collapse column was successfully mitigated.

\section{References}

Dong SN. 2016. Study on the Optimal Allocation of Water Resources Systems and the Comprehensive Utilization of Water Resources in Arid-Semiarid Multiple Mining Areas, Springer Publishing Company.

Li GY, Zhou W. 2015. Karst paleo-collapses and their impacts on mining and the environment in northern China. NCKRI symposium 5, Proceedings of 14th Sinkhole Conference, 147-156.

Zhou W, Beck BF. 2011. Engineering Issues on Karst, in van Beynen PE (editor): Karst Management. Springer Dordrecht Heidelberg London New York.

Zhou WF. 1997. Paleocollapse structure as a passageway for groundwater flow and contaminant transport. Environmental Geology 32 (4):251-257. 